\title{
THE HISTORY OF ANAESTHESIA IN CANADA*
}

\author{
H. J. SHIELDS, M.B., F.R C.P.(C), F.F.A.R.C.S. (ENG.)**
}

WHEN anaesthesia was given to the world, Canada was a young country not yet a nation; Confederation was some twenty years in the future. The population in 1848 numbered scarcely two million, the large majority being located on the eastern seaboard and in Lower and Upper Canada with a few white settlers in the regions west of the Creat Lakes. There were no great cities such as exist today, most of the inhabitants, many of French extraction, were busily engaged in clearing the forests to create farm lands or in the fur trade. Canada in those days was a land of hardy pioneers.

In the early years of the colony's history the medical profession was built up mainly from adventurous spurts who reached the new land as ships' surgeons, these remaining chiefly in Lower Canada. Some undoubtedly were ill prepared from a professional standpoint. In Upper Canada, which became a province in 1791, the profession drew its numbers largely from British army surgeons who were stationed in Canada before and durng the War of 1812 and remained in the colony after returng from the services. Some of these were of high professional standing By the year 1815 there were all told in the province 36 physicians, the majority of these being in York which was to be incorporated as the City of Toronto in 1824. It was not until the year 1843 that physicians could obtain their degrees in their natıve land In that year L'École de Médecin et Chirurgie was established in the City of Quebec. In Upper Canada a Medical Board was created by Iaw in 1818 with authority to hold examinations. These were held at York. In the year 1843, Dr John Rolph founded a Medical School which in 1848 became known as the Toronto School of Medicme and was incorporated as such in 1853 At this penod medical journals published in Canada were few in number. The earliest appears to have been the Quebec Medical Journal inauguraled in 1826. The first publications in English were the British American Journal of Medical and Physical Science and the Montreal Medical Gazette, both establıshed in the year 1845 and publıshed in Montreal British periodicals were of course avallable to the profession and it is to be hoped that they had a wide curculation in the country. It may be recorded that Wells, Morton and Simpson made their great contribution to mankind at the period when Canadian physicians for the first time could obtain medical education in their own country and have access to medical publications of Canadian origin

It is possibly surprising, and certainly pleasing to record how soon after the developments abroad, anaesthesia was put into practice in the colony. In the June 1ssue, 1847, of the British American Journal of Medical and Physical Science,

\footnotetext{
"Presented to the Section of Anaesthesia at the conjoint meeting of the British Medical Association and the Canadian Medical Association, Toronto, Ont , June 23, 1955

* Toronto General Hospital
} 
Horace Nelson, M.D. (1) of Montreal repolted the results of experiments with Ether on animals, his friends, and by self administration. He stated that while he could not attempt to give a perfect explanation of the mode of action of the agent he believed the nerves of sensation to be first affected with those of motion later. A few days following these trials he assisted his father in the removal of a tumour weighing two pounds from the thigh of a woman rendered unconscious with Ether. He also recorded the extraction of teeth from a number of patients in the same manner. He proposed further experimentation on animals with the view of determining the physiological action of Ether by causing death from direct overdosage and examining post-mortem the brain and the nervous system in general. If carried out these investigations have not come to light. This publication appeared within a few months of Morton's demonstration in Boston. Other writers of the time were impressed with the superionty of Ether over Nitrous Oxide so it is apparent that the use of this agerit was prevalent.

The honour of the first use of Chloroform in Canada appears to belong to Dr. A. F. Holmes (2), Professor of Theory and Practical Medicine, McGill College. In the British American Journal of Medical and Physical Science, February 28,1848 (his article was dated January 25),-the author records what he believed to be the first application of this agent in the province (probably the first in Canada). Obstetrical patients were the recipients, the dosage he employed was small according to later practices He obtained the drug from Messris S. J. Lyman \& Co., Montreal. In the various journals of the period other contributors rejort the use of Chloroform E. D. Worthington, MD (3), Sherbrooke, Que sec, records three admmistrations in an article dated February 10 In a report from Pictou, Nova Scotia, we learn that a chemıst, J. G. D. Fraser by name, made some Chloroform from a formula obtained from a British publication for use in his own wife's confinement. In the volume containing Holmes's report a method of manufacture of Chloroform is outlined, there is also a reprint under the headıng "Perıscope" of Simpson's famed communication dated at Edinburgh November 22, 1847, entitled "Discovery of a New Anaesthetic Agent More Effective than Sulphuric Ether." In this journal of the same date are to be noticed several reprints from British publications on the various aspects of Ether anaesthesia. It is interesting also to find a report in detail including the proceedings of a coroner's court with comments of medical witnesses, amongst whom was John Snow, on a death from Chloroform in Britain.

From a study of the medical journals of the time the impression is gathered that the introduction of Chloroform into the anaesthetic field created an increasing interest in anaesthesia in general. The volurne of the literature in the medical and lay publications with reference to Chloroform was considerably in excess of that occasioned by the introduction of both Nitrous Oxide and Ether. The contributors in general recognized the dangers of Chloroform anaesthesia and though the belief was prevalent that anaesthesia should be effected rapidly, there is evidence of a definite opinion that high concentrations were to be avoided. We may assume in any event that the use of Ether and Chloroform was widely adopted throughout the country at these early dates.

The impetus provided by the introduction of anaesthesia made revolutionary 
changes in surgical practices-throughout the entire medical world. As the science of surgery developed the need for greater interest and skill in anaesthesia became apparent. Though some years were to pass before new agents and methods appeared, interest in this aspect of medicine was maintained in Canada as elsewhere. Throughout the years following 1847, reports are to je found in varıous Canadian publications concerned mostly with individual preferences for agents and techniques of administration. In the Dominion Medical Journal published at Toronto we find that Dr. A. M. Rosebrugh (4) on November 28, 1868, addressed the Medical Section of the Canadian Institute of that city, the tıtle of his communicator being "Chloroform." He described at some length his personal views after seven years' experience as to the method of administration and the mode of action of this agent. It may be noted that the subscription fee for this journal was $\$ 2.00$ per annum. In a volume of the Canada Lancet, dated 1873, Dr. W. S. Coleman (5), assistant surgeon of the Toronto Eye and Ear Infirmary, reports the use of Chloroform on fifty patients during the previous year. In the same journal appears an editorial outlining the advantages of Ether over Chloroform anaesthesia. Several references also are found to spinal anaesthetic practices, generally pointing out the dangers associated therewith Anaesthesia held a place of secondary importance, no doubt, in the activities of all these communicants. It is reasonable, nevertheless, to accept the premise that here and there as the operating room assumed greater importance in hospital régimes, some physician showng special aptitude in the subject became known as an anaesthetist This interest probably woutd be a part-time occupation with him at first. From such beginnings however the specialty of anaesthesia emerged. Untıl large hospitals eame into being and the surgeon widened his fields of endeavour there could be no full-time anaesthesia. The names of some of these physicians are recorded; the contribution provided by their activities should not be forgotten in a history of this nature

Coming to more recent tumes the picture becomes clearer. In all sections of the country certain figures emerge as pioneers in the development of anaesthesia as a definite science and specialty. In Nova Scotia, Muir at Halifax; LaRocque at Hôtel-Dieu, Montreal, prepanng the way in French-speaking Canada; Howell, Nagle and later Bourne all of Montreal are well remembered by the older generation of anaesthetists still amongst us Of these Muir and Bourne are still active In Ontario, Samuel Johnston's is a figure which looms large in the annals of Canadian anaesthesia. Following his internshp, completed in 19013, he was given the task of organizing an anaesthetic service at the Toronto General Hospital. In 1907 he was officially appointed Lecturer at the University of Toronto at which time he devoted himself exclusively to the teaching and practice of his specialty. He became affectionately known as the Dean of Canadian Anaesthesia. Prior to his appointment, Stevenson, Scadding, and John Caven had some prominence in the anaesthetic field at Toronto. In Western Canada we find recorded in the minutes of the proceedings of the Winnipeg General Hospital dated 1899 that Dr. Hutton who had been acting anaesthetist to the hospital since 1893 was officially appointed Honorary Anaesthetist, a post which William Webster assumed in 1902 and was to hold with distinction for 
many years. In 1905 Webster was appointed Lecturer in Anaesthesia to the Medical Faculty of the University of Manitoba at Wirnipeg. In 1907 he became a full-time specialist in his subject. He was one of the first anaesthetists on this contment to engage in experimental research in animals. In 1924 he published a text book The Science and Art of Anaesthesia which for many years was the basis of teaching in his area. In Britısh Columbia sorne time prior to 1912, Dr. J. W. Thompson was appointed anaesthetist to the Vancouver General Hospital, and following him came Bastın and Freeze.

Johnston and Webster were particularly assiduous in the early years in the preparation of scientific papers directed to anaesthetısts and the profession in general. These two proneering spirits were among the first on this contunent to organize departments in therr respective universities for the teaching of their subject to undergraduate students. Each, realizing the necessity of better anaesthesia and possibly sensing the developments soon to come, built up physician staffs to meet these needs. At other teaching centres their example was soon followed. When, therefore, in the early years of the present century new agents together with improved anaesthetic appliances appeared on the scene and surgical sciences at the same tume reached into new fields, Canadian anaesthesia was in a position to accept and exploit these new responsibilities.

By the year 1920, enthusiasm and numbers had reached the point where it was deemed imperative to organize. With Dr. Wesley Bourne the leading spirit, the Canadian Society of Anaesthetists was inaugurated and incorporated with Dr. Samuel Johnston as President, and Bourne as Secretary. To this adventure came the McMechans, Frank and Laurette, regular attendants at our meetıngs, eager as always to give enthusiastic support to projects anywhere advancing the cause of anaesthesia. Meetıngs were held annually for a period of seven years at the end of which time the Society disbanded to become the Anaesthetic Section of the Canadian Medical Association. In 1943 the Canadian Anaesthetists' Society was organized and is now a floursshing body with upwards of six hundred members and a creditable journal under the able editorship of Dr. Roderick Gordon of Toronto. Sections of anaesthesia exist in the Canàdıan Medical and in several of the provincial Associations.

Canada may be proud of the contribution to anaesthesia on the part of workers in the basic sciences and of practising anaesthetssts. Dr. Wesley Bourne, though busily engaged in anaesthetic practice, was associated for many years with the Department of Pharmacology, McGill University. He was the author or coauthor of a number of original treatises dealing with the effects on body organs and functions of the various anaesthetic agents and allied drugs. The undergraduate student passing through this department received an unusually good grounding in the pharmacological effects of anaesthetic substances. Dr. Bourne also presented many papers related to the clnical aspect of the newer anaesthetics. His many accomplishments brough him numerous honours, the most notable possibly being the first award of the H1ckman Medal. H1s university has seen fit to instal him as Professor Emeritus, an honour not lightly bestowed at ${ }^{\circ}$ McGill. $\mathrm{He}$ is the only Canadian ever elected to the office of President of the American Society of Anesthesiologists. He was chosen by the World Health 
Organization to further the sicience of anaesthesia in Europe, a labour from which he has just recently returned. The scientific attainments and the gift of oratory together with a remarkable personality have resulted in his being much sought after in this country and abroad as the principal speaker at functions of various natures. Dr. Bourne has been for many years and still remains an outstanding personality in the anaesthetıc world. At Toronto, Professor Velyien Henderson, whlle Chief of the Departmient of Pharmacology at the University of Toronto, was keenly interested in problems related to anaesthesia. Over the years he and his co-workers delved into the pharmacological effects particularly of the newer anaesthetic agents, some of which were used for the first time in his own laboratory. The many publications emanating from his department have made his name known throughout the anaesthetic world.

In March, 1923, Dr. W. Easson Brown (6), a member of the anaesthetic staff of the Toronto General Hospital, workıng part-tıme in Professor Henderson's laboratory, presented before the Toronto Academy of Medicine his experiments, anımal and human, with Ethylene, an agent which he believed he was using for anaesthetic purposes for the first time. He was quite unaware of the more extensive research with this agent being undertaken by Lickhart and his group at Chicago, whose fine paper appeared a short time after Brown's publication. In 1929, Professors Lucas and Henderson (7) introduced Cyclopropane into the anaesthetıc field. It was not untl 1933 however, that Waters at Madison, Wisconsin, was able to persuade one of the manufacturers of anaesthetic gases to provide him with enough material to institute further clinical trials. Dr. Harold Gruffith (8) of Montreal is another Canadian whose name will be recorded in anaesthetic history $\mathrm{H}_{1 \mathrm{~s}}$ projection of curare into anaesthesia has had more farreaching effects in anaesthetic practices than possibly any other recent innovation. For many anaesthetısts the world over techniques have undergone changes mostly desirable as a direct result of his contribution. Griffith, like his long-time associate, Dr. Bourne, is a tireless worker, whose activities extend in many directions $\mathrm{He}$, too, has been the recipient of many honours, one of these being chaurmanship of the committee which dealt with the formation of the World Federation of Societies of Anesthesiologists The inaugural meeting of this body is to be held shortly in Holland.

Canadian anaesthetısts were impressed at an early date with the virtues of endotracheal adminıstration of anaesthetıc agents. At an International Medical Congress held in London in 1913, Professor Meltzer of New York, whose contributions to this subject did much to popularize it, was a principal speaker. His paper evoked much discussion on the part of many prominent anaesthetists from Britain and elsewhere. Amongst these was William Nagle (9) of Montreal, who reported his experiences with three hundred administrations. In 1927, Hargrave (10) of Toronto described a wire-woven silk-covered elastic catheter, one of the early practical wide bore tubes. He stressed the value of a catheter of this nature in operations such as tonsillectomy employing nitrous oxide insufflation alone or supplemented with ether.

Canada has an excellent record in relation to the Medical Services in general in the armed forces at home and abroad in war and peace. The importance of 
anaesthesia as part of these services has always been recognized. In World War I, Robson, now of Toronto, was attached as anaesthetist to No. 1 Canadian General Hospital recruited in Montreal, the first large medical unit to go overseas. The writer, then a member of the anaesthetic staff of the Toronto General Hospital, followed shortly after in the same capacity with No. 4 Canadian General Hospital. Both units were designated as training centres for medical personnel, who after varying periods of instruction were attached to hospitals in more forward areas. Robson's department and my own were supplied with the most modern anaesthetic equipment available at that date and each of us was familiar with and employed endotracheal administration methods. In World War II experienced physician anaesthetsts were attached to all large hospital units. Training faclities were made avallable immediately at home to ensure a continuing supply as new hospital groups came into being. A large centre of this nature was set up at Montreal where under the auspices of Bourne and his associates physician personnel were given four months' intensive instruction, both practical and in basic sciences. Simllar training was available also at Toronto under the writer's direction. Contributions of merit to anaesthetic problems more or less peculiar to war casualties were contributed by our anaesthetic services overseas, one of the most notable being R. A. Gordon's (11) intravenous use of procaine in the management of burns and for the relief of pain in the transport of the severely wounded. As in World War I overseas training facilities for physıcian personnel were establıshed under the direction of S. M. Campbell of Toronto and others to fill growing needs as hostilities expanded.

As the fund of medical knowledge increases, the need for larger numbers of specially trained physicians becomes apparent. Our rapidly increasing population necessitates the building of more hospitals, many of which are being located in well-populated outlying distncts A determmed effort is being made to supply these institutions with tramed staffs From the postgraduate training centres young physicians and surgeons well equpped in their specialties are gravitatıng to these smaller cities and towns. Without equally advanced anaesthesia much of their usefulness would be lost. To meet the need the various postgraduate anaesthetic courses are filled to capacity. The McGll threeyear Diploma Course has an enrolment of thirty or more. At Toronto, Hálifax, Vancouver, Edmonton, and Saskatoon, simllar unstruction is available, mostly on a two-year course basis. In French-speaking Canada similar facilities exist at the University of Montreal and Laval University at Quebec. Graduates, after four years' training and practice, may be certificated in their specialty after successful completion of the examination sponsored by the Royal College of Physicians and Surgeons of Canada. Fellowship in the College is also avalable when certain other requirements such as one year's study in a postgraduate medical course are met. While the supply from these sources does not yet meet the demand imposed by the country's developing economy, more and more hospitals are being provided with modern anaesthesia.

We belıeve that the anaesthetic structure in Canada rests on good foundations. Scattered across the land are a goodly number of anaesthetists, French-speaking 
and English-speaking, some with reputations reaching beyond our borders, whose names have not appeared in this history. The Mantime Provinces are represented by such men a.s Muir, Stoddart, and Lunney. In French-speaking Canada, to mention a few only, are Cousineau, Hudon, and Longtin. At Montreal, Griffith is supported by such well-known figures as Gilbert, Slater, and others in his undergraduate and postgraduate responsibilities. At Toronto, Campbell, who has succeeded the writer as Chief of the Department, has Gordon, Junkin, and a fine group of progressive and energetic confrères. Queen's University and the University of Western Ontario have active departments as has the University of Manitoba at Winnipeg. Leech is prominent in Saskatchewan. A department has been established recently under Wyant at the University of Saskatchewan, Saskatoon. Anaesthesia at the University of Alberta, Edmonton, is under the able direction of E. A. Gain. Vancouver has a large and energetic group with a most enterprising programme for the new medical school at the University of Britsh Columbia, with Graves in charge. There is no place or need in our country for nurse anaesthesia. Canada has been unfortunate in losing several of its most bighly qualified anaesthetists to the larger fields to be found south of our border. We are thankful that a number of others have resisted the pressure brought to bear on them from that direction. Those of us who have had the good fortune to be on the scene here during the great developments in the anaesthetic world in the past thirty or forty years, and who have taken some part, perhaps, in the bulding of the present structure, have no fear for the future of anaesthesia in Canada. We know that it rests in very able hands.

\section{REFERENCES}

1 Nelson, Horace Brit Am J Med Phys Sc 334 (1847)

2 Holmes, A F Brit. Am 「 Med Phys Sc. 3 263 (1848).

3 Worthington, E D. Brt Am J Med Phys Sc 3 326 (1848)

4 Rosebrugh, A M Dom Med J 1 64 (1868)

5 Coleman, W S Can Lancet 5617 (1873).

6 Brown, W E CM A J 3 210 (1923)

7 Lucas, G H W \& Henderson, V E C M A J 21173 (1929)

8 Griffith, H R \& Johnston, Enid C M A J 5144 (1944).

9 Nagle, W Brit Med J 2393 (1913)

10 HaRgrave, R CMAJ 17688 (1927)

11 Gondon, R A C M A J 49478 (1943) 